\title{
The Moderating Role of Market, Firm and Supply Chain Factors on the Relationship between Information Technology Practices and Supply Chain Agility
}

\author{
Inda Sukati*, Abu Bakar Hamid, Rohaizat Baharun, Noriza Mohd Jamal \\ Department of Business Administration, Faculty of Management, Universiti Teknologi Malaysia (UTM), \\ Johor Bahru, Malaysia \\ Email: ${ }^{*}$ indasukati@utm.my, ${ }^{*}$ indasukatiutmjb@gmail.com
}

Received 17 January 2014; revised 17 February 2014; accepted 28 February 2014

Copyright (C 2014 by authors and Scientific Research Publishing Inc.

This work is licensed under the Creative Commons Attribution International License (CC BY).

http://creativecommons.org/licenses/by/4.0/

c) (i) Open Access

\begin{abstract}
In complex business environment, most firms are facing pressures to respond proactively to the environmental factors rapidly and be innovative and effective in order to survive. Therefore, organizations are required to be agile, and have the right information at the right time to make better decisions. In this paper, we examine the linkage between information technology practices (ITP) and supply chain agility (SCA). This study also analyzes the moderating role of market, firm and supply chain factors on the relationship between ITP and SCA. The data collection instrument used was a questionnaire which was administrated to a total sample of 500 respondents from food and beverages industry in peninsular Malaysia. The number of questionnaire collected was only $130(26 \%)$ and the number of usable questionnaire was $100(20 \%)$. The analyses involved statistical methods such as reliability and validity tests, correlation analysis and multiple regressions. The result suggested that ITP have positive impact on SCA. These findings suggest that firm should consider ITP that can improve SCA.
\end{abstract}

\section{Keywords}

Information Technology Practices, Supply Chain Agility, Firm, Market, Supply Chain Factors

\section{Introduction}

In the global competition, rapidly changing customer demand and preference and the accelerating pace of tech"Corresponding author.

How to cite this paper: Sukati, I., et al. (2014) The Moderating Role of Market, Firm and Supply Chain Factors on the Relationship between Information Technology Practices and Supply Chain Agility. American Journal of Industrial and Business Management, 4, 258-266. http://dx.doi.org/10.4236/ajibm.2014.45033 
nological change have pushed the business that is becoming increasingly uncertain environment and turbulent [1]-[3]. Intensive rivalry, the proliferation of rapid product introductions and customized products, and the convergence of computing, communications and content technologies require firms to adapt quickly in order to achieve and maintain a competitive advantage [3]-[8]. The ability of a firm to respond its competition can achieve a sustainable competitive advantage and it is a key important factor to success in today's global marketplace [7]-[11].

The concept of agility has been issued in many literatures and management debate. Many authors, such as [1] [4] [8] [12] [13] argue that agility is the ability to sense and respond effectively to market changes and has become imperative to create and maintain a competitive advantage in today's volatile global markets. Firms are facing the growing need to increase agility by leveraging information technology practices (ITI) to sense changes in the market and to orchestrate a coordinated response to these changes throughout the supply chain [2] [3] [7] [8] [14].

The main objective of this research is to investigate the link between information technology (IT) and supply chain agility. This study also examines the moderating role of market, firm and supply chain factors in terms of number of supplier, supplier value added, and level of integration on the relationship between information technology and supply chain agility.

To achieve the research objective, this paper has structured the following sections including this introduction. Sections two and three cover the literature review and research framework and hypotheses formulation, followed by describing the methodology used in section four. Section five highlights the finding of the research.

\section{Literature Review}

[15]-[17] argue that the ability of a firm to be agile is to sense and respond to market changes is imperative in today's global economy. It is widely agreed that a single firm cannot achieve supply chain agility in isolation, but instead in collaboration with its supply chain members [1]. Increasingly, information technology is viewed as enabling supply chains to sense and respond to markets effectively and efficiently [2] [3] [8] [14].

To sense market changes, firm requires collecting high quality information on changes in the market. The quality of information is essential as it is the basis for decision making throughout the supply chain [18] [19]. The use of information technology can enable sharing of high quality market information such as customer demand, competitor actions, and technology trends [2] [8] [20] [21].

There are various definitions for information quality provided by reviewing literature; however, it is the concept of "fitness for use" that is most prevalent [8] [22]-[24]. This definition takes the perspective of assuring quality based on user needs within organizations and between organizations [8] [22]-[24]. Further, there is an abundance of attributes and dimensions that have been identified in the literature that explain information quality in more measurable terms. According to [25] the attributes of information quality are complete, concise, reliable, timely valid, accessible, appropriate amount, credible relevant and understandable. Furthermore, [24] argued that the components of information quality are intrinsic data quality: consists of accuracy, objectivity, believability, and reputation; Contextual data quality: consists of value-added, relevancy, timeliness, completeness, and appropriate amount of data; Representational data quality: consists of interpretability, ease of understanding, representational consistency, and concise representation; Accessibility data quality: consists of accessibility and access security. Information quality content, Information content, which consists of accurate, complete, concise, useful in daily jobs, and relevant for decision making; and information format, which consists of good appearance and format, consistency, and easy to understand. [23] examines that information quality can be measured by using various variable such as currency, completeness, accuracy, compatibility, and convenience of access to information.

To develop the information quality attributes tested in this study a combination of [49] and [35] data quality categories and [23] attributes were leveraged. These authors' research was leveraged for various reasons. First, their attributes are well accepted in the research community and adopted in other studies. Second, various other studies have adopted similar attributes, or a subset of their attributes. Finally, these attributes are relevant to this study's focus on supply chain; that is, specifically [23] focused on the effects of information quality on supply chain agility. This study consisted of the following information quality attributes: timely, accurate, adequate, and accessible.

Information technology practices can make an important role in sensing market changes by managing large amounts of data that are processed and leveraged by the supply chain. Information technology practices facili- 
tate the flow and processing of information across the supply chain [17] [26] which can improve the timeliness, accessibility, accuracy and adequacy of information. The quality of this information and all supply chain information flows has only been achievable through the developments in IT [27]-[29]. Information quality improvements are one of the main drivers for ITP in the supply chain [30] [31]. As a result of IT, the entire supply chain is able to easily share useful and accurate information [20]. This is supported by empirical research that has shown that firms that use IT have higher information quality [8] [23] [32] [33].

Responding to market changes requires a firm to collaborate with the members of its supply chain in order to ensure an effective and efficient response. IT can improve a firm's ability to respond to volatile markets [34] [35] by coordinating a plan with the supply chain that addresses the changes in the market in a timely, accurate, and cost effective manner [7] [9]-[11]. In today's global and volatile markets, supply chain collaboration has gained importance and as a result, it is the focus of much research to be explored in this section.

Information sharing among supply chain members is an important element of collaboration, [17] [36]-[40] and can enable better planning and executing of supply chain operations [21] [41]. IT can enable information to be shared within the supply chain to develop and coordinate a plan to respond to market changes. IT can reduce the time, reduce the total cost, and increase the effectiveness of developing and executing a coordinated plan throughout the supply chain. Coordinating with the supply chain allows the firm to respond better to market changes than when acting alone [42].

\section{Moderating Role of Market, Firm and Supply Chain Factor on the Relationship between Information Technology and Supply Chain Agility}

According to [8] a various number of factors may significant influence to the degree of information technology practices impacts supply chain agility such as market, firm, and supply chain factors. More specifically, the effectiveness of information technology in enhancing the agility of supply chain might be moderated by these variables [8].

The market or industry consists of numerous factors that could influence the impact of information technology on agility of supply chain. [2] [43]-[45] stated that the factors could be include for example the character of the particular industry, degree of competition, rate of technological change and the stability of customer demand. Some markets or industries invest their money in information technology at various rates and use different technologies. The level of industry or market competition faced by any firms could determine the firm's value that IT provided by information technology [43] hence, the effect of information technology may enable the agility of supply chain. Furthermore, [2] argue that the difference rate of technological change among markets or industries could impact the requirement of a firm to adapt technological, competitive, and many other changes in the market or industry and the speed at which they respond to the market change. The stability or instability of market demand might influence the ability of any firms to respond to the market needs. Companies that have relative high market demand instability could invest in information technology in order to make the firms increase their able to respond effectively to an uncertainty market at different rates than firms with stable market [40].

Another factor that may influence the impact of information technology on agility of supply chain is the firms. The firms can include the size of the firm that can be measured by sales revenue, the degree of globalization as measured by the percent of the sales and the competitive strategy the firm pursues to create and maintain a competitive advantage. The firm size could affect the availability of firm resources to invest in information technology.

[46]-[48] argue that the supply chain structure and the nature of interrelationships among firms in the supply chain may also influence the impact of information technology on agility of supply chain. The supply chain structure consists of suppliers, value added by all suppliers, and the supply chain integration level. The number of suppliers and supplier value added provide an indication of the complexity of the supply chain. More complex supply chains, more coordination among members required. So, information technology may have different levels of effectiveness on agility of supply. The level of supply chain integration as measured integration within the firms, firms-supplier integration and firms-customer integration may determine the impact of agility supply chain.

Numerous previous scholars (e.g., [4] [7] [13]) investigate that firms could create and maintain a competitive advantage by increasing leveraging information technology to sense and respond to market changes in order to 
improve supply chain agility. However, there are a few studies about the effectiveness of information technology practices on supply chain agility [8].

The foundation of supply chain integration is information sharing of customer demand in real-time, which allows the supply chain to respond to the market with greater agility [49]-[51] and competitiveness [45]. Information sharing within the supply chain reduces demand uncertainty by providing members with greater visibility to make better decisions in response to customer [38] [39] [46]. The level of supply chain integration can also be determined by joint planning and joint decision-making, which align supply chain members on specific decisions to be made within planning and operational contexts [42]. Joint planning and joint decision-making within the supply chain lead to improvements in order fulfillment measurements and delivery performance ultimately leading to enhanced responsiveness [21] [27] [38].

\section{Research Framework and Hypotheses}

This study adapted from many scholars such as [8] [19] [23] [24] [32] [37] work with some modifications. The above authors agreed that information technology has the high influence on supply chain agility.

Based on above literature review, the conceptual model can be drawn as follow.

As shown in Figure 1 the research framework developed for this study is based on the extent to which information technology practices (ITP) improve supply chain agility (SCA). This figure is the operational definition for the constructs in this study. Specifically, the model empirically tested the extent to which information technology practices improve the quality of information on market changes communicated throughout the supply chain; and the extent to which information technology improves the supply chain's ability to respond to market changes by planning and executing a coordinated response in a timely, accurate, and cost effective manner. The model also tested the impact of critical market, firm, and supply chain factors on the effectiveness of information technology practices in improving supply chain agility.

Hence, the following hypotheses will be tested:

$\mathrm{H}_{1}$ : ITP has positive impact on SCA.

$\mathrm{H}_{2}$ : The impact of ITP on SCA is moderated by market.

$\mathrm{H}_{3}$ : The impact of ITP on SCA is moderated by firm.

$\mathrm{H}_{4}$ : The impact of ITP on SCA is moderated by supply chain factors.

\section{Research Methodology}

\subsection{Data Collection Method}

This study focuses on Malaysian manufacturing industry, especially in food and beverages industry. The respondents ask to indicate on scale of 1 (minimum) to 5 (maximum) on the extent to which information technology practices that can bring to improvement of supply chain agility. The unit of analysis of this study was selected from food and beverage product industry in Peninsular Malaysia. Food and beverage product Manufac

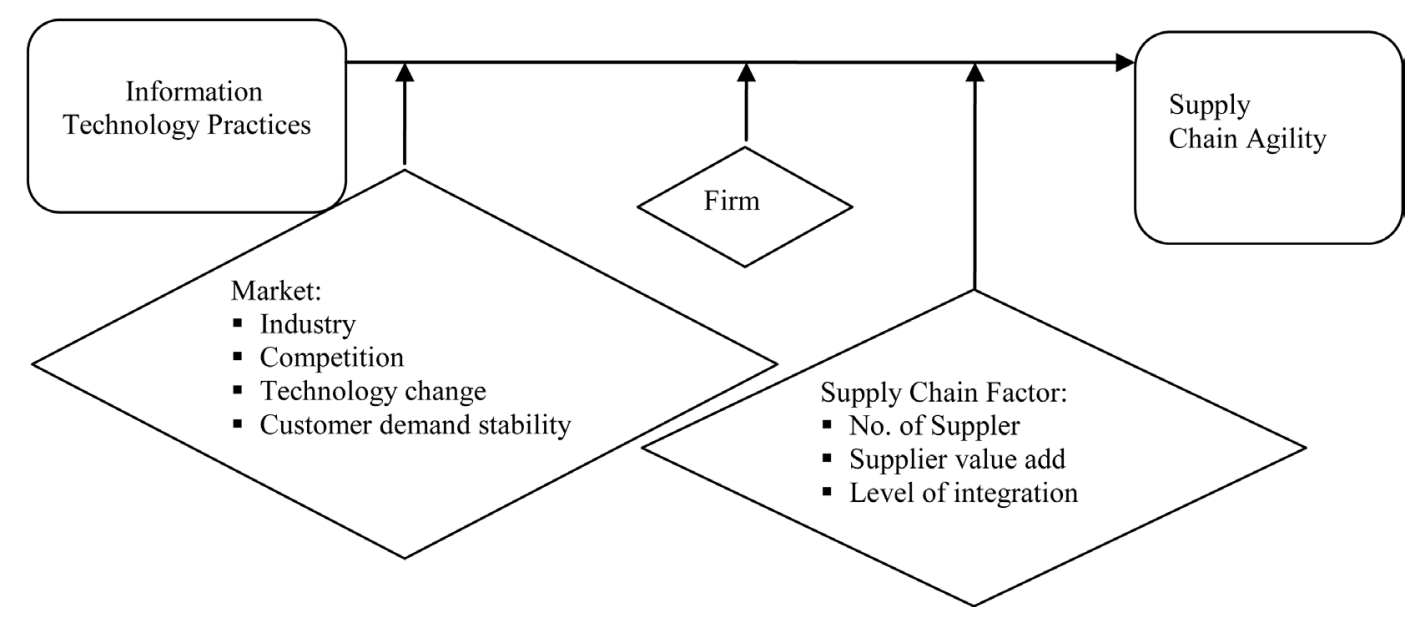

Figure 1. Proposed research framework. 
turing and retailer firms were selected because they can cover the entire spectrum of supply chain activities so they must both sense and respond to market changes to produce products that meet the needs of constantlychanging markets. The survey instrument developed to test the research hypotheses is also not able to accommodate the varying nature of supply chain activities of both manufacturers and retailers. Specifically manufacturers and retailers would be analysed in two different stratums, which may reduce the survey sample when analysing the moderating effect of market, firm, and supply chain factors. From the list of food and beverage product industry, there are around 500 firms (This database can be used for research population). There are 23 manufacturer's categories in Malaysia (see http://companylist.org/Malaysia/Keywords/Manufacturing/) but this study only focus on food and beverages industry.

Purposive sampling is one of non-probability samplings. This is used when researchers want to access a particular subset of people. Researchers chose the sample based on who they think would be appropriate for research. This research used purposive sampling because the sample of this study is part of a particular person is owner, president/CEO, vice presidents, directors, managers and senior staff.

Before distributing the questionnaire, the questionnaire draft was tested with five managers of Food and Beverages Company. The questionnaires were sent to target respondents by e-mail. By using e-mail, researchers attached a form so that all respondents could include any relevant information. All the forms were returned using e-mail also after a phone follow-up within the expected deadline. After a telephone follow-up process, 100 fully complete questionnaires were obtained (20\%), giving sample error of $\pm 8.5 \%$ with a confidence level of $95 \%$.

\subsection{Respondent's Response Research Variable}

This survey involved 500 respondents from food and beverages industry in peninsular Malaysia. The number of questionnaire collected was only 130 (26\%) and the number of usable questionnaire was 100 (20\%).

\subsection{Reliability and Validity Instrument}

The research instrument has been tested for measuring reliability and validity on use of information technology constructs that consist of five items, namely; the use of IT to sense market changes in customer demand, competitor action, and technology trend, ITP to respond by developing coordinated plan with supply chain, executing a coordinated plan with supply chain. Supply chain agility construct consists of ten items, namely; quality information in terms of adequacy, accuracy, accessibility, timeliness, developed coordinated plan with supply chain in terms of cost, and effectiveness, execute coordinated plan with supply chain in terms of timeliness, cost, and effectiveness.) Cronbach's alpha test was used for internal consistency reliability of the ITP and supply chain agility.

The Cronbach's alpha $(\alpha)$, and factor loadings applied for the Information technology practices. The five-item ITP construct Cronbach's alpha of 0.82 , it shows that good reliability. We use factor loadings to evaluate the model fit of a construct. The factor loadings less than 0.4 indicate low and more than 0.6 as high. It represents the five individual ITP items showed high construct/content validity; 0.64, 0.78, 0.80, 0.85 and 0.87 . The results of reliability and validity testing indicate that the ITP construct has both high reliability and high content/construct validity in measuring the use of IT in firms to supply chain agility. The Cronbach's alpha $(\alpha)$, and factor loadings also applied for the supply chain agility construct. The 10-items supply chain agility construct had a Cronbach's alpha of 0.92 , which indicated very good reliability. The ten of individual supply chain agility items showed high construct/content validity ranging from 0.77 to 0.95 . The results of reliability and validity testing indicate that the supply chain agility construct has extremely high reliability and extremely high content/construct validity in measuring the agility of the firm's supply chain in sensing and responding to market changes.

The Cronbach's alpha $(\alpha)$, and factor loadings applied for the, market, firm, and supply chain factors. The researcher extracted three individual factors from thirteen questions and the factor loading of all question were higher than 0.5. The first factor is market, composed of four questions: industry, degree of competition, pace of technology change and stability of customer demand. The Cronbach's $\alpha$ of these questions score: 0.85 . The second factor, firm, composed of: sales revenue, competitive strategy differentiation, competitive strategy low cost and the Cronbach's $\alpha$ of these questions score: 0.82 . The third factor, supply chain factors, composed of five questions: number of suppliers, percent of supplier's value added, information sharing, joint planning and decision making. The Cronbach's $\alpha$ of these questions score: 0.91 . 


\subsection{Correlation Analysis}

Factors that influence the variance (VIF) were calculated to determine whether there are levels of multicollinearity. The VIF in this model has information technology relatively low inter-correlations between independent variables that indicated that no serious multicollinearity.

Correlation techniques are used to explore the relationship and prove the relationship hypothetical two or more variables when the data forming the second variable interval or ratio, and source of data from two or more variables is the same.

Correlation between independent variable (information technology) and dependent variable (supply chain agility) is calculated and linier regression analysis is used in order to verify the correlation.

In this research, Pearson's Product Moment of Coefficient Correlation, and multiple correlation are applied to examine correlation and predict degree of information technology and supply chain agility. The value of $r$ should range between -1.0 and 1.0 and determines the extent and type of correlation between the variable. A value close to extremities indicates a high correlation and indicates whether the correlation is negative or positive. A close-to-zero value indicates no correlation and a value in between indicate the existence of correlation to some moderate degree depending on the value.

The correlation between independent variables (ITP) and dependent variable (SCA) and moderating variable (market, firm and supply chain factors) was positive. ITP had a correlation of $0.31, \mathrm{p}<0.01$ with SCA. It means that the respondents are more likely to evaluate ITP positive when SCA rated positive.

The correlation got higher with SCA when the moderator variables (market, firm and supply chain factors) interact with the independent variables (ITP). The interaction of IT and market (ITXM) scored the correlation of $0.68, \mathrm{p}<0.01$. The interaction of IT and firm (ITXF)) scored the correlation of $0.64, \mathrm{p}<0.01$. The interaction of IT and supply chain factors (ITXSCF) scored the correlation of $0.83, \mathrm{p}<0.01$.

These correlations mean that the moderating variable (Market, firm and supply chain factors) played significant role in the relationship ITP and SCA.

\subsection{Testing Model}

The effects of ITP on SCA are assessed by using multiple linier regression analyses suggested by Baron and Kenny (1986); Bian \& Moutinho (2011). Multiple linear regression analyses are used to develop models relating the ten measures of SCA to the five independent variables (ITP1 - ITP5). Table 2 shows coefficients of each model along with corresponding test statistics. To test the hypotheses, researcher starts regress between ITP and overall SCA. Researchers evaluated the contribution of each set of variables by determining the significance of the F-value associated with the change in Adj. $\mathrm{R}^{2}$ after each was introduces (Pehazur and Schmelkin, 1991; Cagliano et., 2006; Jose et al., 2012)

\section{Finding}

The results of multiple regression analysis are shown in Table 1 . In model 1 where the dependent variable is overall supply chain agility, the model seems to be reliable ( $\mathrm{p}$-value for $\mathrm{F}<0.01$ and adjusted R-square of 0.48 . The Model showed that $48 \%$ of SCA is related to ITP. The result in Table 1 appears to confirm $\mathrm{H}_{1}$.

A moderator variable is the independent qualitative or quantitative variable that affects the relationship of the dependent and independent variables. Effect of moderator variables indicates variables that strengthen or weaken the relationship between independent variables with dependent variables.

Table 2 shows the regression between all integrated variables (ITXM, ITXF and ITXSCF) to examine the moderating effect on the relationship between ITP and SCA. Table 2 shows the regression between all integrated variables (independent and interaction) to examine the moderating effect on the relationship between ITP and SCA. The adjusted coefficient of determination of the model is $\mathrm{R}^{2} 0.223$ with $\mathrm{p}$-value $<0.01$. As a result, the interaction term (ITXM, ITXF and ITXSCF) was significantly related to SCA.

\section{Summary and Conclusions}

The purpose of this study is to investigate the linkage between ITP and SCA. This study also examines the moderating effect of market, firm and supply chain factors on the relationship between ITP and SCA. 
Table 1. Model parameter estimates of supply chain Agility (SCA) (t-value in parenthesis).

\begin{tabular}{cc}
\hline & DV $=$ Overall SCA \\
\hline Constant & $115.03(7.42)^{* *}$ \\
ITP1 & $0.94(2.15)^{* *}$ \\
ITP2 & $1.52(3.51)^{* *}$ \\
ITP3 & $1.32(3.2)^{* *}$ \\
ITP4 & $1.62(3.3)^{* *}$ \\
ITP5 & $1.75(3.4)^{* *}$ \\
Adj R & 0.48 \\
F value & $12.25^{* *}$
\end{tabular}

$\mathrm{p}^{*}<0.1, \mathrm{p}^{* *}<0.05, \mathrm{p}^{* * *}<0.001$.

Table 2. The moderating test of firm, market and supply chain factors on the relationship between ITP and Supply Chain Agility and the interaction term (t-value in parenthesis).

\begin{tabular}{cc}
\hline & SCA \\
\hline Constant & $28.60(21.90)^{* *}$ \\
ITXM & $0.025(3.544)^{* *}$ \\
ITXF & $0.024(3.544)^{* *}$ \\
ITXSCF & $0.021(3.544)^{* *}$ \\
Adj R & 0.223 \\
F value & $25.567^{* *}$ \\
\hline
\end{tabular}

$\mathrm{p}^{*}<0.1, \mathrm{p}^{* *}<0.05, \mathrm{p}^{* * *}<0.001$.

The results of this study indicated a significant relationship between ITP and SCA and the correlation got higher with SCA variable when the moderator variables (market, firm and supply factor) interact with SCA.

In this research, the following outcomes were obtained: (a) The correlation analysis showed that ITP (1) is related to SCA (2). This study also found that moderating variables (firm, market and supply chain factor) moderate the relationship between ITP and SCA.

Hypothesis1 evaluated the relationship between ITP and overall SCA. This study found a significant relationship between ITP and overall SCA. The results show that 48\% of SCA is related to ITP. While Hypothesis 2 - $4\left(\mathrm{H}_{2}-\mathrm{H}_{4}\right)$, which considered the moderating effect of market, firm and supply chain factors on the relationship between ITP and SCA and testing found that there is significant correlation suggests that market, firm and supply chain factors does moderate the relationship between ITP and SCA.

\section{References}

[1] Ganguly, A., Nilchiani, R. and Farr, J.V. (2009) Evaluating Agility in Corporate Enterprises. International Journal of Production Economics, 118, 410-423. http://dx.doi.org/10.1016/j.ijpe.2008.12.009

[2] Overby, E., Bharadwaj, A. and Sambamurthy, V. (2006) Enterprise Agility and the Enabling Role of Information Technology. European Journal of Information Systems, 15, 120-131. http://dx.doi.org/10.1057/palgrave.ejis.3000600

[3] Sambamurthy, V., Bharadwaj, A. and Grover, V. (2003) Shaping Agility through Digital Options: Reconceptualizing the Role of Information Technology in Contemporary Firms. MIS Quarterly, 27, 237-263.

[4] Goldman, S.L., Nagel, R.N. and Preiss, K. (1995) Agile Competitors and Virtual Organizations: Strategies for Enriching the Customer. Van Nostrand Reinhold, New York.

[5] Moore, G.A. (2000) Living on the Fault Line: Managing for Shareholder Value in the Age of the Internet. HarperCollins Publishers, New York.

[6] Venkatraman, N. and Henderson, J.C. (1998) Real Strategies for Virtual Organizing. Sloan Management Review, 40, 33-48. 
[7] Yusuf, Y., Gunasekaran, A., Adeleye, E. and Sivayoganathan, K. (2004) Agile Supply Chain Capabilities: Determinants of Competitive Objectives. European Journal of Operational Research, 159, 379-392. http://dx.doi.org/10.1016/j.ejor.2003.08.022

[8] De Groote, S.E. (2011) An Empirical Investigation of the Impact of Information Technology on Supply Chain Agility and Firm Performance among U.S. Manufacturers. Ph.D. Thesis, Lawrence Technological University, College of Management, USA.

[9] Porter, M.E. (1991) Towards a Dynamic Theory of Strategy. Strategic Management Journal, 12, 95-117. http://dx.doi.org/10.1002/smj.4250121008

[10] Prahalad, C. and Hamel, G. (1990) The Core Competence of the Corporation. Harvard Business Review, May-June, 79-91.

[11] Teece, D.J., Pisano, G. and Shuen, A. (1997) Dynamic Capabilities and Strategic Management. Strategic Management Journal, 18, 509-533. http://dx.doi.org/10.1002/(SICI)1097-0266(199708)18:7<509::AID-SMJ882>3.0.CO;2-Z

[12] Lin, C.-T., Chiu, H. and Chu, P.-Y. (2006) Agility Index in the Supply Chain. International Journal of Production Economics, 100, 285-299. http://dx.doi.org/10.1016/j.ijpe.2004.11.013

[13] Yusuf, Y., Sarhadi, M. and Gunasekaran, A. (1999) Agile Manufacturing: The Drivers, Concepts and Attributes. International Journal of Production Economics, 62, 33-43. http://dx.doi.org/10.1016/S0925-5273(98)00219-9

[14] Van Oosterhout, M., Waarts, E. and van Hillegersberg, J. (2006) Change Factors Requiring Agility and Implications for IT. European Journal of Information Systems, 15, 132-145. http://dx.doi.org/10.1057/palgrave.ejis.3000601

[15] Agarwal, A., Shankar, R. and Tiwari, M.K. (2007) Modeling Agility of Supply Chain. Industrial Marketing Management, 36, 443-457. http://dx.doi.org/10.1016/j.indmarman.2005.12.004

[16] Christopher, M. and Towill, D. (2001) An Integrated Model for the Design of Agile Supply Chains. International Journal of Physical Distribution \& Logistics Management, 31, 235-246. http://dx.doi.org/10.1108/09600030110394914

[17] Christopher, M. (2000) The Agile Supply Chain: Competing in Volatile Markets. Industrial Marketing Management, 29, 37-44. http://dx.doi.org/10.1016/S0019-8501(99)00110-8

[18] Price, R. and Shanks, G. (2005) A Semiotic Information Quality Framework: Development and Comparative Analysis. Journal of Information Technology, 20, 88-102. http://dx.doi.org/10.1057/palgrave.jit.2000038

[19] Stvilia, B., Gasser, L., Twidale, M.B. and Smith, L.C. (2007) A Framework for Information Quality Assessment. Journal of the American Society for Information Science \& Technology, 58, 1720-1733. http://dx.doi.org/10.1002/asi.20652

[20] Li, X., Goldsby, T.J. and Holsapple, C.W. (2009) Supply Chain Agility: Scale Development. International Journal of Logistics Management, 20, 408-424. http://dx.doi.org/10.1108/09574090911002841

[21] Simatupang, T.M. and Sridharan, R. (2002) The Collaborative Supply Chain. International Journal of Logistics Management, 13, 15-30. http://dx.doi.org/10.1108/09574090210806333

[22] Ballou, D., Madnick, S. and Wang, R. (2003) Special Section: Assuring Information Quality. Journal of Management Information Systems, 20, 9-11.

[23] Petersen, K.J., Ragatz, G.L. and Monczka, R.M. (2005) An Examination of Collaborative Planning Effectiveness and Supply Chain Performance. Journal of Supply Chain Management, 41, 14-25. http://dx.doi.org/10.1111/j.1055-6001.2005.04102002.x

[24] Wang, R.Y. and Strong, D.M. (1996) Beyond Accuracy: What Data Quality Means to Data Consumers. Journal of Management Information Systems, 12, 5-33.

[25] Gustavsson, M. and Jonsson, P. (2008) Perceived Quality Deficiencies of Demand Information and Their Consequences. International Journal of Logistics: Research \& Applications, 11, 295-312. http://dx.doi.org/10.1080/13675560801952987

[26] Vickery, S.K., Droge, C., Setia, P. and Sambamurthy, V. (2010) Supply Chain Information Technologies and Organisational Initiatives: Complementary versus Independent Effects on Agility and Firm Performance. International Journal of Production Research, 48, 7025-7042. http://dx.doi.org/10.1080/00207540903348353

[27] Auramo, J., Kauremaa, J. and Tanskanen, K. (2005) Benefits of IT in Supply Chain Management: An Explorative Study of Progressive Companies. International Journal of Physical Distribution \& Logistics Management, 35, 82-100.

[28] Barratt, M. (2004) Understanding the Meaning of Collaboration in the Supply Chain. Supply Chain Management, 9, 30-42. http://dx.doi.org/10.1108/13598540410517566

[29] Miller, H. (1996) The Multiple Dimensions of Information Quality. Information Systems Management, 13, 79-82. http://dx.doi.org/10.1080/10580539608906992 
[30] Nath, T. and Standing, C. (2010) Drivers of Information Technology Use in the Supply Chain. Journal of Systems and Information Technology, 12, 70-84. http://dx.doi.org/10.1108/13287261011032661

[31] Hartono, E., Li, X., Na, K.S. and Simpson, J.T. (2010) The Role of the Quality of Shared Information in Interorganizational Systems Use. International Journal of Information Management, 30, 399-407. http://dx.doi.org/10.1016/j.ijinfomgt.2010.02.007

[32] Moyano-Fuentes, J., Martinez-Jurado, P.J., Maqueira-Marin, J.M. and Bruque-Camara, S. (2012) Impact of Use of Information Technology on Lean Production Adoption: Evidence from the Automotive Industry. International Journal of Technology Management, 57, 132-148.

[33] Gustavsson, M. and Wänström, C. (2009) Assessing Information Quality in Manufacturing Planning and Control Processes. International Journal of Quality \& Reliability Management, 26, 325-340. http://dx.doi.org/10.1108/02656710910950333

[34] Bhatt, G.D. and Grover, V. (2005) Types of Information Technology Capabilities and Their Role in Competitive Advantage: An Empirical Study. Journal of Management Information Systems, 22, 253-277.

[35] Zaheer, A. and Zaheer, S. (1997) Catching the Wave: Alertness, Responsiveness and Market Influence in Global Electronic Networks. Management Science, 43, 1493-1509. http://dx.doi.org/10.1287/mnsc.43.11.1493

[36] Arshinder, Kanda, A. and Deshmukh, S.G. (2008) Supply Chain Coordination: Perspectives, Empirical Studies and Research Directions. International Journal of Production Economics, 115, 316-335. http://dx.doi.org/10.1016/j.ijpe.2008.05.011

[37] Chong, A.Y.L., Ooi, K.B. and Sohal, A. (2009) The Relationship between Supply Chain Factors and Adoption of E-Collaboration Tools: An Empirical Examination. International Journal of Production Economics, 122, 150-160. http://dx.doi.org/10.1016/j.ijpe.2009.05.012

[38] Simatupang, T.M. and Sridharan, R. (2008) Design for Supply Chain Collaboration. Business Process Management Journal, 14, 401-418. http://dx.doi.org/10.1108/14637150810876698

[39] Whipple, J.M. and Russell, D. (2007) Building Supply Chain Collaboration: A Typology of Collaborative Approaches. International Journal of Logistics Management, 18, 174-196. http://dx.doi.org/10.1108/09574090710816922

[40] Wiengarten, F., Humphreys, P., Cao, G.M., Fynes, B. and McKittrick, A. (2010) Collaborative Supply Chain Practices and Performance: Exploring the Key Role of Information Quality. Supply Chain Management: An International Journal, 15, 463-473.

[41] Power, D.J., Sohal, A.S. and Rahman, S.U. (2001) Critical Success Factors in Agile Supply Chain Management-An Empirical Study. International Journal of Physical Distribution \& Logistics Management, 31, 247-265. http://dx.doi.org/10.1108/09600030110394923

[42] Goldsby, T.J. and Stank, T.P. (2000) World Class Logistics Performance and Environmentally Responsible Logistics Practices. Journal of Business Logistics, 21, 187-208.

[43] Dong, S.T., Xu, S.X. and Zhu, K. (2009) Information Technology in Supply Chains: The Value of IT-Enabled Resources under Competition. Information Systems Research, 20, 18-32. http://dx.doi.org/10.1287/isre.1080.0195

[44] Lee, H.L., Padmanabhan, V. and Whang, S. (2004) Information Distortion in a Supply Chain: The Bullwhip Effect. Management Science, 50, 1875-1886. http://dx.doi.org/10.1287/mnsc.1040.0266

[45] Mason-Jones, R. and Towill, D.R. (1999) Total Cycle Time Compression and the Agile Supply Chain. International Journal of Production Economics, 62, 61-73. http://dx.doi.org/10.1016/S0925-5273(98)00221-7

[46] Lummus, R.R. and Vokurka, R.J. (1999) Managing the Demand Chain through Managing the Information Flow: Capturing “Moments of Information”. Production \& Inventory Management Journal, 40, 16-20.

[47] Lummus, R.R., Vokurka, R.J. and Krumwiede, D. (2008) Supply Chain Integration and Organizational Success. SAM Advanced Management Journal, 73, 56-63.

[48] Simatupang, T.M. and Sridharan, R. (2005) Supply Chain Discontent. Business Process Management Journal, 11, 349369. http://dx.doi.org/10.1108/14637150510609390

[49] Gunasekaran, A., Lai, K.h., and Cheng, T.C.E. (2008) Responsive Supply Chain: A Competitive Strategy in a Network Economy. International Journal of Management Science, 36, 549-564.

[50] Evrard-Samuel, K. (2008) Sharing Demand Signals: A New Challenge to Improve Collaboration within Supply Chains. Supply Chain Forum: An International Journal, 9, 16-27.

[51] Horvath, L. (2001) Collaboration: The Key to Value Creation in Supply Chain Management. Supply Chain Management: An International Journal, 6, 205-207. http://dx.doi.org/10.1108/EUM0000000006039 